\title{
Mucocele eroding maxillary sinus wall as an incidental finding in Cone-beam computed tomography: a case report
}

\author{
- Felipe Seizo Ioshitaqui Shidomi Department of Stomatology, School of Dentistry, University of São Paulo, São \\ Paulo, Brazil - Ricardo The Chen Department of Stomatology, School of Dentistry, University of São Paulo, São Paulo, \\ Brazil • Luciana Munhoz Department of Stomatology, School of Dentistry, University of São Paulo, São Paulo, Brazil • Emiko \\ Saito Arita Department of Stomatology, School of Dentistry, University of São Paulo, São Paulo, Brazil
}

ABSTRACT | Mucoceles are locally-expansive, slow-growing benign lesions that are generated from obstructed seromucous glands in the sinonasal mucosa. It has a cystic aspect and leads to sinus opacification. Patients usually present non-specific opacification and, in rare cases, enlarged mucoceles can lead to bone destruction through the compression of sinus surrounding bone walls. This report shows the case of a female patient without any clinical complaints who presented an evident opacification in her left maxillary sinus eroding the sinus wall, which was noticeable by means of panoramic radiograph, aside from maxillary sinus wall thinning and destruction, demonstrated through cone beam computed tomography examinations. The main diagnosis hypothesis was mucocele, as confirmed by the patient's otolaryngologist. As the presence of any inflammatory disease in the maxillary sinus contraindicates sinus augmentation, the patient was referred to otorhinolaryngy treatment before implant rehabilitation.

DESCRIPTORS | Maxillary Sinus; Mucocele; Cone-beam Computed Tomography; Paranasal Sinus Disease.

RESUMO | Mucocele com reabsorção da parede do seio maxilar: relato de caso • As mucoceles são lesões benignas localmente expansivas, de crescimento lento, que se desenvolvem a partir de glândulas seromucosas obstruídas na mucosa nasossinusal. Os pacientes geralmente apresentam radiograficamente opacificação inespecífica de aspecto cístico e, em casos raros, mucoceles de grandes proporções podem levar à destruição óssea, por meio da compressão do seio ao redor das paredes ósseas. Neste relato, é demonstrado um caso de uma paciente do gênero feminino, sem queixas clínicas, que apresentava evidente opacificação em seu seio maxilar esquerdo, erodindo a parede sinusal, observada inicialmente em radiografia panorâmica. Por meio da tomografia computadorizada de feixe cônico, notou-se afinamento e erosão da parede do seio maxilar. A principal hipótese diagnóstica foi mucocele, confirmada posteriormente pelo otorrinolaringologista da paciente. Como a presença de qualquer doença inflamatória no seio maxilar é uma contraindicação a cirurgias em soalho de seio maxilar, a paciente foi encaminhada para tratamento otorrinolaringológico antes da reabilitação com implantes.

DESCRITORES | seio maxilar, mucocele, tomografia computadorizada cone beam, doença sinusal.

CORRESPONDING AUTHOR | - Luciana Munhoz Department of Stomatology, School of Dentistry, Sao Paulo University - Avenue Prof. Lineu Prestes, 2227, Butantã, São Paulo, SP, Brazil • 05508-000 E-mail: dra.lucimunhoz@usp.br 


\section{INTRODUCTION}

Mucoceles are locally-expansive, ${ }^{(1)}$ slow-growing, benign lesions of paranasal sinus that are generated from obstructed seromoucous glands in the sinonasal mucosa. ${ }^{(2)}$ The gland obstruction results in a cystic formation, due its dilation and continuing mucous accumulation, ${ }^{(2)}$ leading to smooth expansive regular mass, sometimes resulting in bone erosion or remodeling. ${ }^{(1,2)}$

Blockage of sinus cell ostium may occur spontaneously or as a result of traumas, infection, chronic inflammation of any nature, allergic rhinosinusitis, neoplasms development, postradiotherapy or post-surgical injury, ${ }^{(3,4)}$ especially after sinus surgery or adjacent areas. Particularly in maxillary sinuses, mucoceles may occur after Caldwell-Luc approach. ${ }^{(3)}$

Patients usually present non-specific symptomatology, however, extensive mucoceles may exhibit nasal obstruction, facial asymmetry, visual alterations $^{(4,5)}$ and even diplopia, depending on the paranasal sinus comprised. ${ }^{(6)}$ In some cases, it may invade the skull base and orbit ${ }^{(7)}$ and, in rare cases, enlarged mucoceles can lead to bone destruction, ${ }^{(5)}$ such as erosion or thickening, through compression of sinus surrounding bone wall.

Among inflammatory sinonasal alterations, mucoceles are infrequent; maxillary sinuses are affected $10 \%$ more often than other sinuses. ${ }^{(5)}$ Regarding location, mucoceles are usually observed in frontal sinuses, less frequent in ethmoid cells and rarely in other sinuses, including maxillary sinus. ${ }^{(8)}$

Sinonasal imaging examination prior to implant treatments, especially when maxillary sinus floor elevation is necessary, is essential to acquire a satisfactory surgical outcome. Conebeam computed tomography (CBCT) is often requested for dental implant planning, and can also allow for sinus examination. Incidental findings of lesions and anatomic variants in maxillary sinus are not uncommon, even in asymptomatic patients. As some of these conditions may require specialized treatment, its recognition is important in dental practice. ${ }^{(9)}$

Thus, the objective of this report is to describe a case of maxillary sinus mucocele in an asymptomatic patient whose maxillary sinus wall eroded, being considered an incidental finding in CBCT.

\section{CASE REPORT}

\section{Case history and clinical findings}

A female Caucasian patient (66 years old) was referred to a private clinic for radiographic examinations, with the objective of performing oral rehabilitation with implants due to missing teeth, with possible sinus augmentation. The patient then underwent cone-beam computed tomography examination, which included full maxilla evaluation. The patient had no clinical complaints and her medical history was unremarkable. Extra-oral examination demonstrated absence of facial asymmetry; intra-oral examination did not evince any atypical finding.

\section{Imaging examinations and treatment approach}

Panoramic radiograph examination and CBCT was performed at Sirona Orthophos CG $3 \mathrm{D}$ (Bensheim, Germany). The acquisition parameters were: $0.5 \mathrm{~mm}$ slice thickness; $1.0 \mathrm{~mm}$ spacing between slices; $250 \mathrm{~mm}$ field of view; $120 \mathrm{kV}$ peak and $250 \mathrm{~mA}$.

Panoramic radiograph showed opacification in the left maxillary sinus, more evident at the lateral wall, as demonstrated in Figure 1, indicating the need of further investigation of maxillary sinus. The floor expansion of maxillary sinus in the alveolar crest direction presented a striking opacification as well.

On CBCT images, left maxillary sinus opacification is evinced by axial slices. In Figure 2A, opacification is already observed in the proximity of 
the sinus floor, and in Figure 2B, bone erosion can be evinced in the lateral maxillary sinus wall.

Additionally, as observed in Figure 3A, the opacification of maxillary sinus is associated with bone remodeling and the erosion of all sinus walls; in Figure 3B, the medial wall is clearly interrupted, demonstrating the aggressive nature of the lesion.

At this point, the main diagnostic hypothesis was mucocele or any other inflammatory sinus disease, such as antral pseudocyst (mucous retention cyst) or rhinosinusitis.
The inflammatory process in the patient's maxillary sinus contraindicated sinus augmentation, which was necessary to restore the adequate volume of alveolar bone aiming for the implants placement. The patient was then referred to otolaryngology treatment before any surgical procedure in the maxillary sinus.

Due to the presence of bone erosion and the need for maxillary sinus elevation, the patient underwent an endoscopic sinus examination. The final diagnosis was determined through evaluation of sinus content removed during the procedure and defined as mucocele of the maxillary sinus.

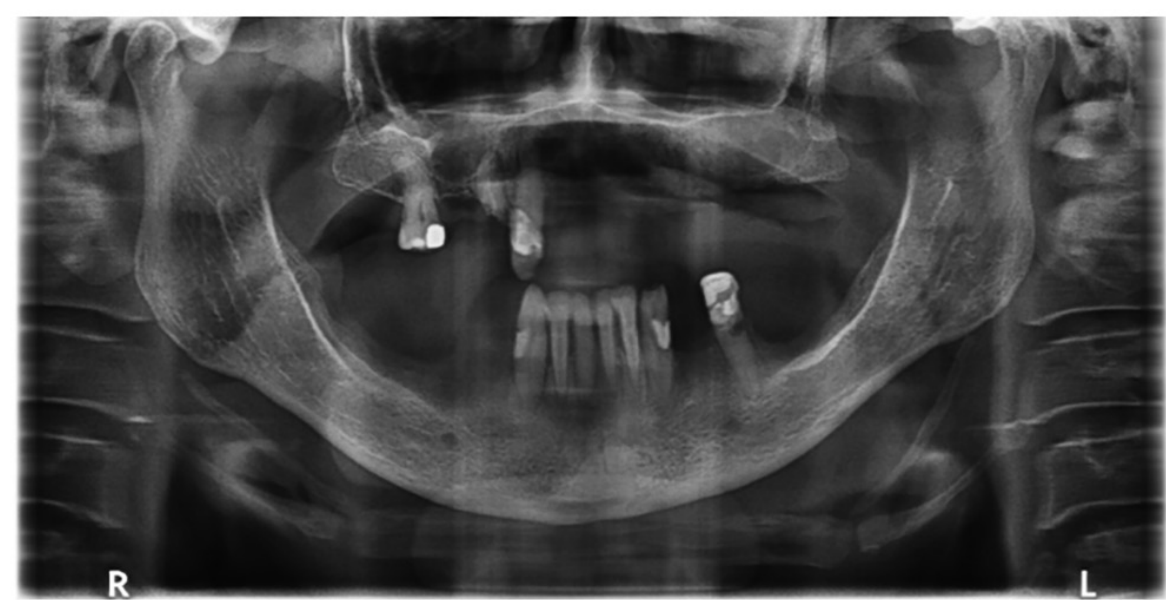

Figure 1 | Panoramic radiograph of the case. Opacification of left maxillary sinus floor and lateral wall.
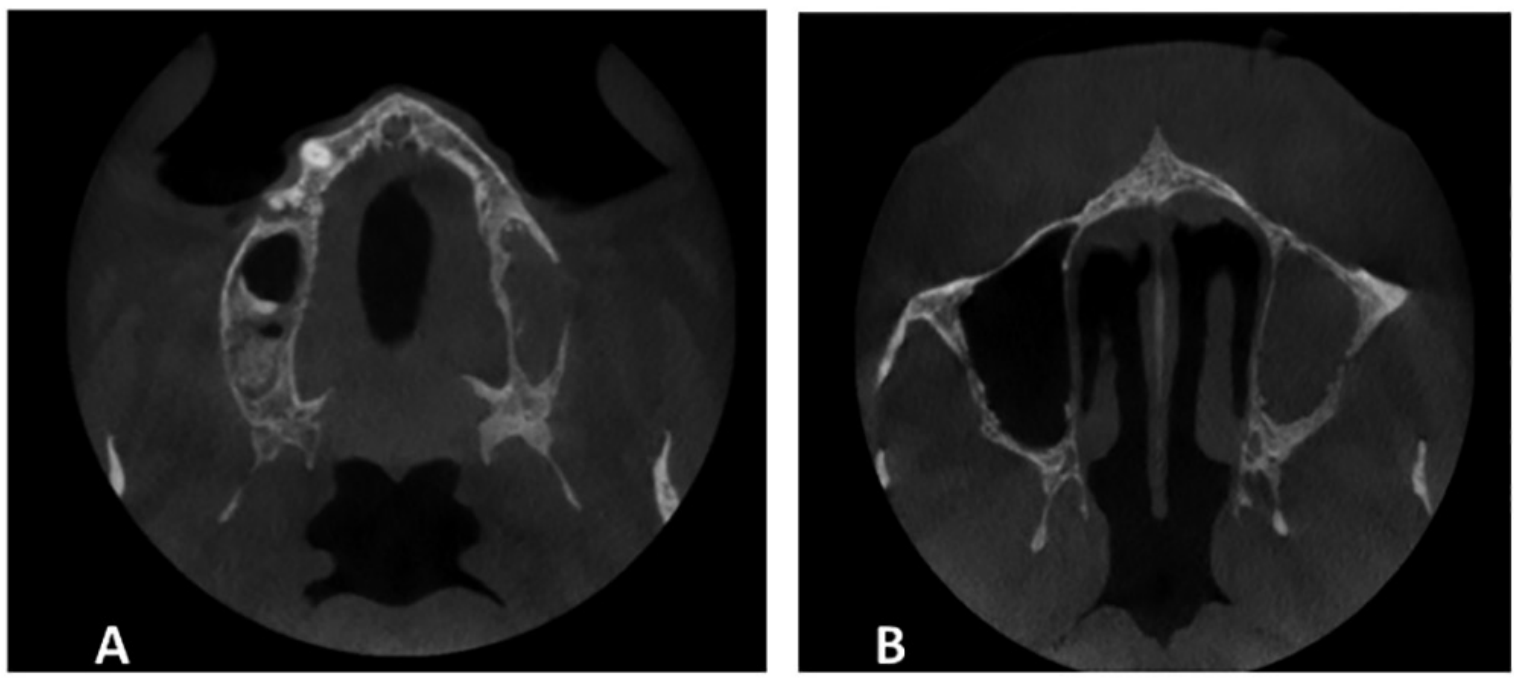

Figure 2 | СВСТ axial slice. A) Opacification in the left maxillary sinus, close to sinus floor; B) Maxillary sinus lateral wall bone subtle interruption. 

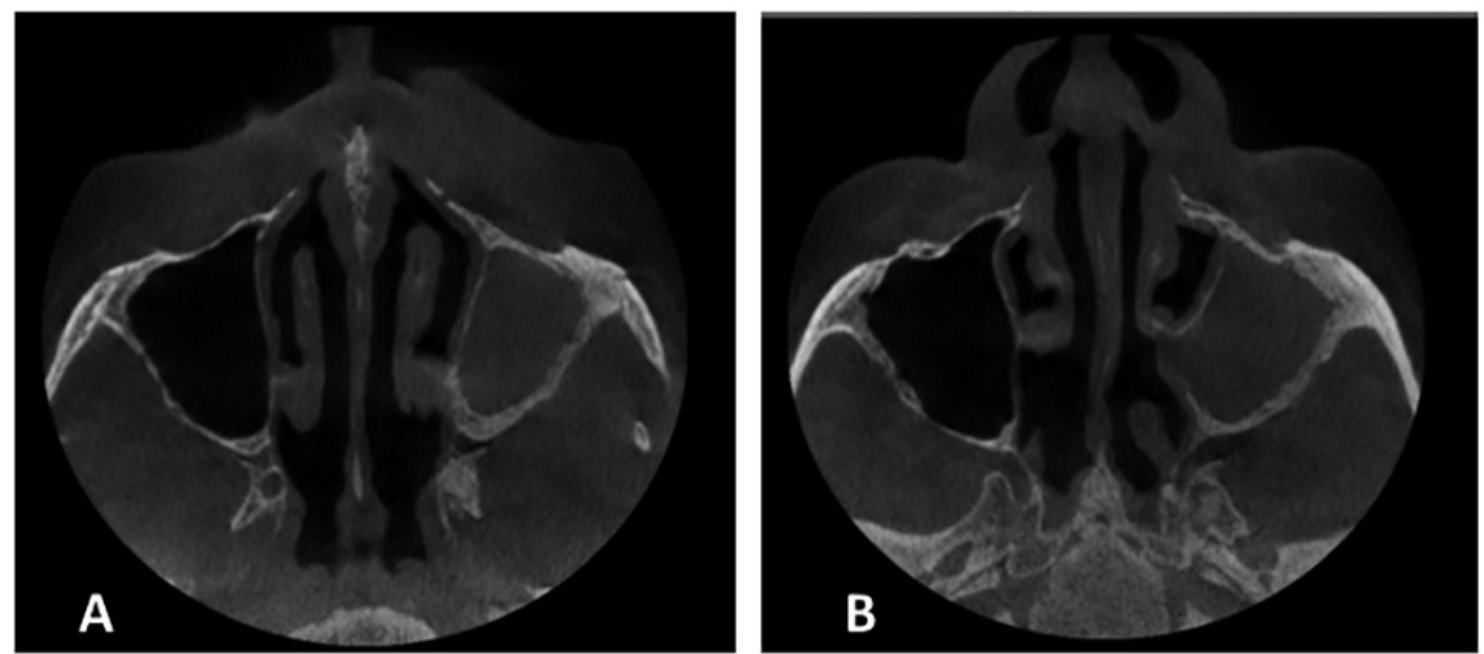

Figure 3 | A) Left maxillary sinus opacification associated with bone remodeling and erosion, mainly in lateral and posterior walls; B) bone interruption of medial wall.

\section{DISCUSSION}

Maxillary sinus inflammatory alterations are highly prevalent in asymptomatic patients, ${ }^{(10)}$ which emphasizes the evaluation importance of the sinus region and related areas before rehabilitation with implants and/or sinus floor elevation. As CBCT examination is usually applied before rehabilitation, the dentomaxillofacial radiologist should undertake a complete assessment of maxillary sinus to detect these alterations.

Mucoceles, as described in this report, are not usual findings in maxillary sinus. Frequently, other inflammatory lesions are incidentally detected in maxillary sinuses previously to implant treatment instead of mucocele. The most usual inflammatory alteration observed is mucosal thickening and polypoid lesions, such as inflammatory polyps or antral pseudocysts. ${ }^{(9)}$ Furthermore, ethmoidal and frontal sinuses are more affected by mucoceles than sphenoidal or maxillary sinuses. ${ }^{(1)}$

Bone remodeling or erosion of maxillary sinus by mucoceles is a rare finding ${ }^{(2,5)}$ and is caused mainly due to the continued mucous secretion of an expanding epithelial-lined mass ${ }^{(11)}$, which leads to bone compression.
The slow progression of maxillary sinus mucoceles and often the lack of acute symptoms lead to a challenging early initial diagnosis. Mucoceles can be asymptomatic for many years. ${ }^{(5)}$ Swelling and unpleasant sensation on the cheek, hemifacial pain, nasal obstruction or discharge are frequently exhibited symptoms..$^{(2,4)}$ When detected too late, the lesion may present considerable volume, which can culminate in expressive symptoms such as exophthalmia, diplopia or even strabismus due to orbital floor invasion. ${ }^{(5)}$ Additionally, large mucoceles may affect skull base..$^{(1)}$

Maxillary sinus mucoceles can be incidentally detected in panoramic radiographs, although it is not the proper imaging examination to maxillary sinuses. The choice of diagnostic examination for mucoceles is computed tomography (CT), the most regularly requested technique. ${ }^{(5)}$ In Dentistry, CBCT can have an important role in identifying asymptomatic lesions prior to undergoing treatment, as it is frequently requested prior to implant treatment. MRI can also be applied, and it is possible to notice the difference in protein content of mucoceles, as the device determines signal characteristics. ${ }^{(12)}$ Contrastenhanced CT or MRI exhibit mucoceles as an 
occluding mass with convoluted cerebriform pattern of enhancement. ${ }^{(12)}$ Bone remodeling or erosion can be detailed/detected by CT, and it is a consequence to maxillary sinus walls compression.

Maxillary sinus mucoceles differential diagnosis includes paranasal antral pseudocysts (mucosal retention cysts), acute sinusitis, ${ }^{(13,14)}$ and paranasal sinus tumors, such as inverted papilloma and antrochoanal polyp. ${ }^{(15)}$ Mucous retention cysts and acute sinusitis imaging resembles maxillary sinus mucoceles due to its predominant mucous content and sinus obliteration, similarly observed in $\mathrm{CT}^{\left({ }^{(13)}\right.}$

The treatment approach for maxillary sinus mucocele may include external approaches, endoscopic treatment and/or combined strategies. ${ }^{(16)}$ Endoscopic access, as applied in the case reported, can be safely used for lesion removal; ${ }^{(16)}$ surgery may be necessary if permanent damage to the surrounding structures are detected.(5)

\section{CONCLUSIONS}

As presence of any inflammatory disease in the maxillary sinus contraindicates sinus augmentation, the patient in the case reported was referred to otolaryngology treatment before implant rehabilitation.

\section{ACKNOWLEDGEMENTS}

We thank to Cristina Yukie Ioshitaqui Shidomi, from Omega Radiologia Odontológica for the technical support in this article.

\section{REFERENCES}

1. Simões JC, Nogueira-Neto FB, Gregório LL, Caparroz FEA, Kosugi EM. Visual loss: a rare complication of maxillary sinus mucocele. Braz J Otorhinolaryngol. 2015;81(4):451-3.

2. Busaba NY, Salman SD. Maxillary sinus mucoceles: clinical presentation and long-term results of endoscopic surgical treatment. Laryngoscope. 1999;109(9):1446-9.
3. Costan VV, Popescu E, Stratulat SI. A new approach to aesthetic maxillofacial surgery: surgical treatment of unilateral exophthalmos due to maxillary sinus mucocele. J Craniofac Surg. 2013;24(3):914-6.

4. Abdel-Aziz M, El-Hoshy H, Azooz K, Naguib N, Hussein A. Maxillary sinus mucocele: predisposing factors, clinical presentations, and treatment. Oral Maxillofac Surg. 2017;21(1):55-8.

5. Pyo SB, Song JK, Ju HS, Lim SY. Reconstruction of large orbital floor defect caused by maxillary sinus mucocele. Arch Craniofac Surg. 2017;18(3):197-201.

6. Kim JS, Kim EJ, Kwon SH. An ethmoid mucocele causing diplopia: a case report. Medicine (Baltimore). 2017;96(50):e9353.

7. Peng X, Yu J, Li Z, Dai J, Tian H, Hu J, et al. [Diagnosis and treatment of nasal sinus mucoceles invaded the skull base and orbit]. Lin Chung Er Bi Yan Hou Tou Jing Wai Ke Za Zhi. 2014;28(13):942-4.

8. Gardner DG, Gullane PJ. Mucoceles of the maxillary sinus. Oral Surg Oral Med Oral Pathol. 1986;62(5):538-43.

9. Lana JP, Carneiro PM, Machado VEC, Souza PE, Manzi FR, Horta MC. Anatomic variations and lesions of the maxillary sinus detected in cone beam computed tomography for dental implants. Clin Oral Implants Res. 2012;23(12):1398-403.

10. Rege IC, Sousa TO, Leles CR, Mendonça EF. Occurrence of maxillary sinus abnormalities detected by cone beam CT in asymptomatic patients. BMC Oral Health. 2012;12:30.

11. Hadar T, Shvero J, Nageris BI, Yaniv E. Mucus retention cyst of the maxillary sinus: the endoscopic approach. Br J Oral Maxillofac Surg. 2000;38(3):227-9.

12. Whyte A, Chapeikin G. Opaque maxillary antrum: a pictorial review. Australas Radiol. 2005;49(3):203-13.

13. Mossa-Basha M, Blitz AM. Imaging of the paranasal sinuses. Semin Roentgenol. 2013;48(1):14-34.

14. Bastaki JM, Schafer DR. Clinical pathologic conference case 4: an incidental maxillary sinus finding. Oral Surg Oral Med Oral Pathol Oral Radiol. 2013;115(5):e44-6.

15. Shikov VG. [Diagnosis and differential diagnosis of mucocele of the maxillary sinus]. Stomatologiia (Mosk). 1965;44:93-4.

16. Scangas GA, Gudis DA, Kennedy DW. The natural history and clinical characteristics of paranasal sinus mucoceles: a clinical review. Int Forum Allergy Rhinol. 2013;3(9):712-7. 